\title{
Campur Kode dan Alih Kode Tim Pewawancara dengan Peserta Wawancara Beasiswa "PIB Berbagi" Tahun Akademik 2018-2019 di Politeknik Internasional Bali
}

\author{
Elsita Lisnawati Guntar \\ Politeknik Internasional Bali \\ E-mail:elsita.lisnawati@pib.ac.id
}

\begin{abstract}
Abstrak. Tujuan penelitian ini ialah untuk mengetahui bentuk dan fungsi penggunaan campur kode dan alih kode antara pewawancara dan peserta wawancara beasiswa "PIB Berbagi" Tahun Akademik 2018-2019. Adapun manfaat yang didapatkan dalam penelitian ini ialah civitas academica PIB memahami tentang bentuk dan fungsi variasi bahasa sebagai sebuah sarana komunikasi yang positif. Selain itu, penelitian ini juga dapat memeperkaya pengetahuan berbahasa civitas akademica PIB. Penelitian ini tergolong dalam penelitian deskriptif kualitatif. Penelitian ini dilakukan di kampus Politeknik internasional Bali yang berlokasi di Jalan Pantai Nyanyi, Banjar Nyanyi, Desa Braban, Tabanan. Metode dan teknik pengumpulan data yang digunakan dalam penelitian ini ialah metode simak melalui teknik sadap dan teknik dokumentasi. Prosedur analisis data dalam penelitian ini menggunakan model analisis interaktif Miles \& Huberman. Hasil penelitian yang ditemukan ialah campur kode dan alih kode yang digunakan oleh tim pewawancara dan peserta wawancara berwujud kata, frasa, klausa, dan kalimat. Wujud campur kode dan alih kode tersebut digolongkan ke dalam campur kode ekstern yaitu campur kode bahasa Indonesia dan bahasa asing (Inggris). Fungsi campur kode dan alih kode antara peserta wawancara dan pewawancara dalam kegiatan tes "PIB Berbagi" ialah 1) untuk menegaskan maksud, 2) untuk memberikan informasi, dan 3) untuk mengakrabkan diri. Kajian campur kode dan alih kode ini diharapkan dapat memperkaya pengetahuan civitas academika PIB dan menjadikannya sebagai sarana komunikasi yang positif dalam dunia pariwisata.
\end{abstract}

Kata Kunci: kajian sosiolinguistik; alih kode; campur kode; fungsi

\section{PENDAHULUAN}

Bahasa adalah sebuah alat komunikasi. Setiap manusia menggunakan bahasa sebagai alat untuk berkomunikasi. Bahasa yang baik dan benar ialah bahasa yang dalam pemakaiannya dapat diterima dan dimengerti baik oleh penutur maupun mitra tuturnya. Sebagai sebuah alat komunikasi, bahasa berpotensi sebagai sarana untuk mencapai suatu keberhasilan dan kesuksesan hidup manusia, baik sebagai insan akademis maupun sebagai warga masyarakat; baik berkomunikasi dalam suatu negara maupun berkomunikasi di antara banyak negara. Penggunaan bahasa yang tepat akan menjadikan seseorang lancar dalam segala urusan. Melalui bahasa yang baik, lawan komunikasi dapat memberikan respon yang positif yaitu memahami maksud dan tujuan komunikasi.

Kaidah berbahasa yang diterapkan dalam komunikasi bahasa Indonesia terdiri atas kaidah linguistik, kaidah sosiolinguistik, kaidah pragmatis, dan kaidah psikolinguistik. Dalam hubungannya dengan ini, komunikasi yang dimaksud dalam penelitian ini ialah komunikasi yang berhubungan dengan kaidah sosiolinguistik yaitu menelaah variasi bahasa. Dalam kajian sosiolinguistik bahasa dipandang sebagai sistem komunikasi dan sistem sosial yang merupakan bagian dari masyarakat dan berkaitan dengan berbagai faktor, baik faktor kebahasaan itu sendiri maupun faktor nonkebahasaan, misalnya faktor sosial budaya yang meliputi status sosial, umur, tingkat pendidikan dan jenis kelamin (Suwito, 1985:76). Kridalaksana (2009:225) mengatakan bahwa sosiolinguistik adalah cabang linguistik yang mempelajari hubungan dan saling pengaruh antara perilaku bahasa dan perilaku sosial.

Sosiolinguistik bukan saja menyoroti masalah bahasa dalam suatu masyarakat melainkan bahasa dengan perilaku sosial. Selain itu, bahasa juga dipengaruhi oleh situasi. Nababan (1994:5) mengutarakan bahwa yang termasuk dalam faktor situasional adalah siapa berbicara dengan siapa, tentang apa, dalam situasi yang bagaimana, dengan tujuan apa, dengan jalur apa dan ragam bahasa mana. Variasi bahasa dalam hal ini timbul karena adanya faktor situasional dan sosial yang mempengaruhi pemakaian bahasa. 
Penggunaan variasi bahasa berupa kode bahasa seringkali ditemukan dalam lingkungan kerja, bisnis, dan komunitas. Fenomena tersebut dilatarbelakangi dan ditentukan oleh situasi dan kondisi yang dihadapi oleh penutur, seperti 1) profesi, banyak orang yang berkerja baik di instansi maupun non instansi dituntut untuk menggunakan lebih dari satu bahasa, 2) fenomena berbahasa di era milenial, ada banyak kaum muda yang melakukan percampuran bahasa dengan alasan percampuran bahasa tersebut dipandang modern dan hight oleh kalangannya.

Pada masyarakat bilingual umumnya terjadi kontak antara bahasa yang satu dengan bahasa yang lain. Kontak yang terjadi terus-menerus antara dua bahasa atau lebih dalam situasi masyarakat bilingual cenderung mengakibatkan gejala kebahasaan yang disebut campur kode dan alih kode.

Campur kode merupakan peristiwa pencampuran dua atau lebih bahasa atau ragam bahasa dalam suatu peristiwa tutur. Sumarsono (2002:202) mengatakan bahwa dalam campur kode (code mixing) penutur menyelipkan unsur-unsur bahasa lain ketika sedang memakai bahasa tertentu. Alih kode adalah peristiwa peralihan dari kode yang satu ke kode yang lain, jadi apabila seorang penutur mula-mula menggunakan kode A dan kemudian beralih menggunakan kode B, maka peralihan bahasa seperti inilah yang disebut sebagai alih kode (Suwito dalam Rahardi, 2001: 10). Hal demikian selalu menjadi gejala menarik dalam studi sosiolinguistik yang disebut sebagai gejala variasi bahasa pada masyarakat bilingual.

Beberapa penelitian yang terkait dengan penelitian campur kode dan alih kode sebagai kajian pustaka dalam penelitian ini ialah Fathurrohman, Sumarwati, dan Sri Hastuti (2013), Mustikawati (2015), dan Ariyani, Munaris, dan Murniati (2015). Dalam penelitian-penelitian terdahulu tersebut ditemukan bahwa penelitian campur kode dan alih kode memang telah banyak dilakukan, seperti yang telah dilakukan oleh Fathurrohman, Sumarwati, dan Sri Hastuti (2013) dalam penelitian berjudul Bentuk dan Fungsi Campur Kode dan Alih Kode pada Rubrik "Ah...Tenane" Dalam Harian Solopos. Perbedaan yang ditemukan ialah campur kode dan alih kode yang diteliti dalam penelitian Fathurrohman dkk berfokus pada bahasa tulisan, sedangkan dalam penelitian campur kode dan alih kode yang ditemukan berfokus pada bahasa lisan yaitu berupa tuturan pewawancara dan peserta wawancara dalam proses seleksi wawancara.

Selain yang dilakukan oleh Fathurrohman dkk, penelitian alih kode dan campur kode juga ditemukan dalam penelitian Mustikawati (2015) yang berjudul Alih kode dan Campur Kode antara Penjual dan Pembeli di Pasar Songgolangit Kabupaten Ponorogo (Analisis Pembelajaran Bahasa Melalui Studi Sosiolinguistik). Perbedaan yang ditemukan ialah penelitian yang dilakukan Kusumawati berfokus pada interaksi berbahasa informal antara penjual dan pembeli di sebuah pasar, sedangkan penelitian ini berfokus pada kegiatan interaksi berbahasa pada situasi formal antara pewawancara dan peserta wawancara di PIB.

Ariyani, munaris, dan Murniati (2015) juga melakukan penelitian berjudul Alih Kode dan Campur Kode pada mahasiswa PBSI dan Implikasinya. Perbedaan yang ditemukan ialah Ariyani dkk meninjau lebih dalam dan detail tentang faktor penyebab alih kode dan campur kode pada mahasiswa Program Studi Pendidikan Bahasa dan Sastra Indonesia dan implikasinya pada pembelajaran bahasa Indonesia di SMA, sedangkan penelitian ini berfokus pada pemaparan bentuk dan fungsi campur kode dan alih kode antara pewawancara dan peserta wawancara "PIB Berbagi". Penelitian-penelitian terdahulu tersebut dapat dijadikan referensi dalam menelaah dan menentukan bentuk alih kode dan campur kode penelitian ini.

Politeknik Internasional Bali (PIB) yang beralamat di Tabanan Desa Beraban adalah sebuah institusi pendidikan bertaraf internasional. Karena itu, PIB mensyaratkan civitas academica untuk berkomunikasi dengan menggunakan dua bahasa (bilingual), dalam hal ini ialah bahasa Inggris dan Indonesia. Praktik bilingual di PIB salah satunya dapat ditemukan dalam pelaksanaan tes wawancara mahasiswa baru. Pada kegiatan tersebut umumnya calon mahasiswa diwawancarai oleh para dosen dengan menggunakan dua bahasa, yaitu bahasa Inggris dan Indonesia. Pada saat itu, terjadilah peristiwa komunikasi bilingual antara tim pewawancara dan calon mahasiswa. Peristiwa komunikasi bilingual tersebut menjadi sangat penting dan menggelitik peneliti untuk menelusuri lebih dalam seperti apakah variasi bahasa yang digunakan tim pewawancara dan peserta wawancara pada saat proses wawancara "PIB Berbagi" Tahun Akademik 2018-2019.

\section{METODE}

\section{Jenis Penelitian}

Penelitian ini tergolong dalam jenis penelitian deskriptif kualitatif. Penelitian kualitatif merupakan salah satu penelitian yang bersifat deskriptif dan cenderung mencari sebuah makna dari data yang didapatkan dari hasil sebuah penelitian. Jenis penelitian seperti ini biasanya digunakan seseorang ketika akan meneliti terkait dengan masalah bahasa, sosial, dan budaya. Sugiyono (2009:6) mengatakan bahwa penelitian kualitatif sering disebut metode penelitian naturalistik karena penelitiannya dilakukan pada kondisi yang masih alamiah (natural setting).

\section{Prosedur Penelitian}

Adapun prosesur yang dilakukan dalam penelitian ini, yaitu 1) membaca literature dan menyiapkan konsep penelitian, 2) melakukan identifikasi masalah, 3) melakukan pembatasan masalah, 4) melaksanakan penelitian, 5) melakukan pengolahan dan pemaknaan data, dan 6) melaporkan hasil penelitian.

\section{Data dan Sumber Data}

Data yang digunakan dalam penelitian ini ialah alih kode, campur kode, dan fungsi campur kode dan alih kode dalam wawancara antara pewawancara dan peserta wawancara "PIB Berbagi” Tahun Akademik 2018-2019. Wujud data dalam penelitian ini berupa kata, frasa, dan kalimat yang digunakan oleh peserta wawancara "PIB Berbagi" dan tim pewawancara. Sumber data primer dalam penelitian ini ialah 
peserta wawancara "PIB Berbagi" Tahun Akademik 20182019 dan tim pewawancara. Selain data primer, sumber data yang dipakai peneliti adalah sumber data sekunder. Sumber data sekunder dalam penelitian ini ialah kajian penelitianpenelitian terdahulu, buku-buku bahasa, referensi, catatan singkat, dan sebagainya yang relevan dengan penelitian ini.

Adapun teknik penentuan sumber data menggunakan teknik purposive sampling yang memfokuskan pada informan-informan terpilih dengan kriteria 1) calon mahasiswa "PIB Berbagi" yang lolos seleksi tulis, 2) dosen/pegawai yang dipercayai institusi untuk menjadi interviewer. Kriteria tersebut diasumsikan cukup untuk mewakili karakteristik yang menggambarkan sumber data dalam penelitian ini.

\section{Metode dan Teknik Pengumpulan Data}

Metode yang digunakan dalam pengumpulan data ialah metode simak dengan teknik dasar yang berwujud sadap. Mahsun (2012:92) mengungkapkan bahwa teknik sadap dikategorikan sebagai teknik dasar dalam metode simak karena pada hakikatnya penyimakan diwujudkan dengan penyadapan. Penyadapan yang dimaksudkan dalam penelitian ini ialah menyadap penggunaan bahasa pewawancara dan peserta wawancara selama kegiatan wawancara berlangsung. Penyadapan dalam penelitian ini dilakukan dengan cara merekam komunikasi bilingual pewancara dan peserta wawancara dengan menggunakan alat batu rekam. Adapun teknik pendukung dalam penelitian ini ilah teknik dokumentasi. Teknik dokumentasi digunakan untuk melengkapi data primer.

\section{Prosedur dan Teknik Analisis Data}

Prosedur analisis data dalam penelitian ini menggunakan model analisis interaktif Miles \& Huberman yang terbagi dalam empat komponen analisis, yaitu 1) pengumpulan data, 2) reduksi data, 3) display data, dan 4) penarikan kesimpulan.

\section{Pemeriksaan Keabsahan Data}

Untuk memeriksa keabsahan data diperlukan teknik triangulasi. Denzin (dalam Moleong 2007:330) membagi teknik pemeriksaan keabsahan data dalam empat jenis yakni 1) triangulasi sumber; 2) triangulasi metode; 3) triangulasi penyidik; dan 4) triangulasi teori. Triangulasi yang digunakan dalam penelitian ini ialah triangulasi sumber. Dalam penelitian ini, hasil analisis dapat berupa sebuah rumusan informasi atau thesis statement. Untuk menguji keabsahannya, informasi tersebut selanjutnya dibandingkan dengan list pertanyaan interview yang diperoleh dari pihak penyelenggara kegiatan, dalam hal ini PIB. Hal ini dilakukan untuk menghindari bias individual peneliti atas temuan atau simpulan yang dihasilkan.

\section{Penyajian Hasil Analisis Data}

Hasil analisis data dalam penelitian ini disajikan dengan menggunakan metode informal. Metode penyajian informal ialah perumusan dengan kata-kata biasa yang diikuti dengan penjelasan secara rinci. Penerapan metode informal dalam penelitian ini tampak pada pemaparan hasil analisis tentang penggunaan campur kode dan alih kode antara peserta wawancara "PIB Berbagi" Tahun Akademik 2018-2019 dengan tim pewawancara dengan menggunakan kalimatkalimat yang diikuti dengan penjelasan secara detail.

\section{HASIL DAN PEMBAHASAN}

Penggunaan variasi kode bahasa dalam masyarakat multibahasa kerap mengundang perhatian banyak orang. Poedjosoedarmo (1976:30) mengungkapkan bahwa kode umumnya berbentuk variasa bahasa yang secara nyata digunakan oleh masyarakat berbahasa dalam berkomunikasi. Dalam penelitian ini akan diulas lebih mendalam tentang bentuk variasi bahasa berupa kode bahasa yang digunakan oleh peserta wawancara wawancara "PIB Berbagi" Tahun Akademik 2018-2019 dengan tim pewawancara.

Bentuk Campur Kode Antara Tim Pewawancara dengan Peserta wawancara "PIB Berbagi" Tahun Akademik 2018-2019

Campur kode umumnya dikenal dan digunakan oleh masyakarakat Indonesia zaman sekarang. Suwito (1985:7879) menyebutkan bahwa campur kode umumnya terdiri dari penyisipan unsur-unsur yang berwujud kata, frasa, klausa, baster, pengulangan kata, dan berwujud ungkapan atau idiom. Berdasarkan pernnyataan Suwito, dalam penelitian ini ditemukan pula peristiwa bahasa berupa penyisipan unsurunsur bahasa.

\section{Campur Kode Berwujud Kata}

Penggunaan campur kode yang berwujud kata dapat dilihat pada data berikut ini.

Pewawancara

Let us start from your experience during the first, second, and have hurd grade of Senior High School, can you tell me, what is your favourite subject? Pelajaran apa yang disukai?

Peserta Matematika

wawancara

(CK/D-4/PIB/2018)

Pertanyaan pewawancara can you tell me, what is your favourite subject menggunakan bahasa Inggris, diikuti dengan penggunaan bahasa Indonesia pelajaran apa yang Anda sukai? Dalam wawancara tersebut ditemukan terjadinya peristiwa campur kode bahasa Inggris dengan Indonesia yang dilakukan oleh pewawancara ketika berwawancara. Campur kode yang ditemukan dalam data 4 ini dikenal sebagai campur kode ekstern.

Campur kode berwujud kata tampak juga dalam wawancara berikut.

Pewawancara

Can you tell me one of your

Peserta achievements?

wawancara

\section{I don't know}


Pewawancara

Peserta

wawancara

Pewawancara

Peserta

wawancara

(CK/D-14/PIB/2018)

Kata ya yang dilontarkan oleh peserta wawancara ketika ditanyai oleh pewawancara tentang prestasi pribadi yang membanggakan peserta wawancara diikuti dengan kalimat bahasa Inggris in the first in the class, when I was grade eleven. Dalam wawancara tersebut ditemukan adanya campur kode berwujud kata ya. Campur kode pada data 14 ini dikenal sebagai campur kode ekstern, yaitu terjadinya percampuran bahasa Indonesia dan bahasa Inggris.

Campur kode berwujud kata juga ditemukan dalam kutipan wawancara berikut.

\begin{tabular}{|c|c|c|}
\hline Pewawancara & & $\begin{array}{l}\text { Have you ever made any } \\
\text { mistake before? What did you } \\
\text { learn from it? }\end{array}$ \\
\hline Peserta wawancara & & Mistake? \\
\hline Pewawancara & & $\begin{array}{l}\text { Yes, jika diterima di PIB, will } \\
\text { you agree to follow all rules } \\
\text { that we have? }\end{array}$ \\
\hline Peserta wawancara & & Sure \\
\hline Pewawancara & & You will do ya? \\
\hline Peserta wawancara & & Yes I do \\
\hline
\end{tabular}

(CK/D-15/PIB/2018)

Pertanyaan yang dilontarkan oleh pewawancara kepada peserta wawancara You will do diikuti oleh Bahasa Indonesia $\boldsymbol{y} \boldsymbol{a}$. Pada data 15 tersebut, kata $\boldsymbol{y a}$ yang digunakan pewawancara termasuk dalam bentuk campur kode berwujud kata.

Campur Kode Berwujud Perulangan Kata

Penggunaan campur kode yang berwujud perulangan kata dapat dilihat pada data berikut ini.

Pewawancara

: Kira-kira pertahun berapa? How many brothers and sisters do you have?

\section{Peserta} : I have one brother

wawancara

(CK/D-1/PIB 2018)

Perulangan kata kira-kira pada data tersebut diikuti dengan pertanyaan lanjutan berbahasa Inggris How many brothers and sisters do you have? Dalam peristiwa komunikasi tersebut ditemukan adanya campur kode bahasa Inggris dan bahasa Indonesia. Campur kode pada data 1 termasuk dalam jenis campur kode ekstern.
Campur kode berwujud perulangan kata ditemukan juga dalam data berikut.

$\begin{array}{ll}\text { Pewawancara } & \begin{array}{l}\text { If you are admitted to PIB, will you } \\ \text { agree to follow all rules in PIB, jika } \\ \text { diterima di PIB apakah Anda mau } \\ \text { mengikuti semua aturan yang } \\ \text { ditetapkan atau Anda pilih-pilih do } \\ \text { you have experience in kitchen or } \\ \text { library? }\end{array} \\ \text { Peserta } & \begin{array}{l}\text { Yes, I have } \\ \text { wawancara }\end{array} \\ \text { Pewawancara } & \begin{array}{l}\text { So to get your experience untuk } \\ \text { mendapat pengalaman di bagian } \\ \text { umum, jadi bisa ya? }\end{array} \\ \text { Peserta } & \text { Bisa }\end{array}$

wawancara

(CK/D-8/PIB/2018)

Perulangan kata pilih-pilih dalam data tersebut diikuti dengan pernyataan berbahasa Inggris do you have experience in kitchen or library oleh pewawancara. Dalam komunikasi tersebut adanya campur kode bahasa Indonesia dan bahasa Inggris. Campur kode perulangan kata pada data 8 tergolong dalam campur kode ekstern.

\section{Campur Kode Berwujud Frasa}

Penggunaan campur kode berwujud frasa dapat dilihat dalam data berikut.
Pewawancara

Peserta wawancara

Pewawancara

Peserta wawancara

Pewawancara

Peserta wawancara (CK/D-5/PIB/2018)

Pada data 5, ketika pewawancara bertanya tentang besaran upah yang diperoleh orang tua peserta wawancara perbulan, peserta wawancara menjawabnya dengan menggunakan dua bahasa yaitu bahasa Inggris maybe one million dan bahasa Indonesia satu juta. Berdasarkan peristiwa komunikasi tersebut ditemukan adanya campur kode frasa bahasa Inggris dan bahasa Indonesia. campur kode tersebut digolongkan dalam campur kode ektern.

Campur kode berwujud frasa dapat dijumpai pada data berikut.

Pewawancara

Peserta wawancara
Who has inspired you in your life? Siapa yang menginspirasi dalam hidup Anda? 
Gurral Perdidikan Bahasa dan Sastra Ondonesia

Pewawancara

: Why? Tell me about your

mom why she is a role

mode?

Peserta wawancara

: $\quad$ She is my motivation,

sebagai penyemangat

(CK/D-6/PIB/2018)

Pada data 6, saat pewawancara menanyakan siapakah yang menginspirasinya dan mengapa ia menjadi role mode dalam kehidupannya, peserta wawancara menjawab dengan menggunakan dua bahasa yaitu bahasa Inggris she is my motivation dan diikuti dengan bahasa Indonesia sebagai penyemangat. Campur kode ini dikategorikan sebagai campur kode ekstern.

Selain itu, campur kode berwujud frasa juga ditemukan juga dalam kutipan wawancara berikut.

\begin{tabular}{|c|c|}
\hline Pewawancara & $\begin{array}{l}\text { If you join in } \mathrm{MPH} \text {, can you tell } \\
\text { me your greater strengths, } \\
\text { kekuatan terbesar... what is your } \\
\text { greatest strength? }\end{array}$ \\
\hline eserta wawancara & Maksudnya? \\
\hline
\end{tabular}

(CK/D-9/PIB/2018)

Campur kode berwujud frasa ditemukan juga saat pewawancara melontarkan pertanyaan If you join in $\mathbf{M P H}$ can you tell me your greater strengts to get that...your strength, dia meneruskannya dengan frasa kekuatan terbesar, dan diteruskan dengan menggunakan Bahasa Inggris what your greatest strength? Dari kutipan tersebut, tampak jelas pewawancara melakukan campur kode bahasa Inggris dan bahasa Indonesia. Campur kode bahasa Inggris dan Indonesia dalam wawancara ini digolongkan dalam campur kode ekstern.

Campur kode berwujud frasa dijumpai pula pada kutipan wawancara berikut.

Pewawancara : Sorry, can you tell me again please, do you mean that you have other father? bapak tiri?

Peserta wawancara : Yes (CK/D-10/PIB/2018)

Pada data 10, pewawancara mengkonfirmasi pernyataan peserta wawancara tentang other father, dalam kutipannya, pewawancara melakukan campur kode bahasa Inggris Sorry, can you tell me again please, do you mean that you have other father dan bahasa Indonesia bapak tiri. Dalam kutipan tersebut ditemukan adanya campur kode berwujud frasa yaitu penggunaan frasa bapak tiri. Campur kode berwujud frasa ini tergolong dalam campur kode ekternal.

\section{Campur Kode Berwujud Klausa}

Campur kode berwujud klausa dapat ditemukan dalam kutipan-kutipan wawancara berikut.
Pewawancara

Peserta wawancara

\section{(CK/D-2/PIB/2018)}

Dalam wawancara tersebut ditemukan adanya campur kode berwujud klausa yaitu ketika peserta wawancara menjawab pertanyaan pewawancara I have juara satu lomba baca tulis cerpen and itu juga ke Manado. Dalam kutipan tersebut ditemukan adanya penggunaan dua Bahasa yaitu bahasa Inggris I have, and dan Indonesia juara satu lomba baca tulis cerpen, itu juga ke Manado. Pernyataan juara satu lomba baca tulis terkmasuk dalam jenis klausa. Campur kode berwujud klausa pada data 2 digolongkan dalam campur kode ekstern.

Campur kode berwujud klausa juga ditemukan dalam data berikut.

Pewawancara

: Do you want to increase your income or do you want to earn money? Mau cari uang tambahan juga?

Peserta wawancara Yes

(CK/D-3/PIB/2018)

Klausa mau cari uang tambahan juga? yang dilontarkan oleh pewawancara dalam kutipan wawancara ialah bentuk campur kode berwujud klausa dan dikategorikan sebagai campur kode ekstern.

Selain itu, campur kode berwujud klausa juga ditemukan dalam kutipan wawancara berikut.
Pewawancara
: So, do you have any experience when you feel that you have done something wrong?
Peserta wawancara : Punya
Pewawancara : Kesalahan apa?
Peserta wawancara : Waktu SD, my friend always juara 1 and then saya merasa iri. Dari situlah saya mulai belajar, study again, again, dan again and finally SMP saya mendapat juara 1 sampai SMA
Pewawancara : Actually, your friends is the one who gives you motivation

\section{(CK/D-7/PIB/2018)}

Pada data 7, campur kode berwujud klausa juga ditemukan ketika peserta wawancara menjawab pertanyaan pewawancara waktu SD, my friend always juara 1 and then saya merasa iri. Dari situlah saya mulai belajar, study again, again, dan again and finally SMP saya mendapat juara 1 sampai SMA. Dari jawaban yang dilontarkan oleh peserta wawancara ditemukannya campur kode klausa saya merasa iri, dari situlah saya mulai belajar, saya mendapat juara 1 sampai SMA. Campur kode berwujud klausa dalam data tersebut termasuk dalam jenis campur kode ekternal. 
Campur kode berwujud klausa pun dapat ditemukan dalam kutipan wawancara berikut.

$\begin{array}{lll}\text { Pewawancara } & : & \text { Who is your inspiration? } \\ \text { Peserta wawancara } & : \text { My parents } \\ \text { Pewawancara } & : \text { Why? } \\ \text { Peserta wawancara } & : \text { Because my parents are } \\ & & \begin{array}{l}\text { mencontohkan hal yang baik } \\ \text { dalam hidupku }\end{array}\end{array}$

\section{(CK/D-17/PIB/2018)}

Pada data 17, peserta wawancara melakukan campur kode bahasa Inggris dan Indonesia, hal ini terbukti pada penggunaan klausa because my parents are mencontohkan hal yang baik dalam hidupku. Campur kode pada data 17 tersebut tergolong dalam campur kode berwujud klausa.

\section{Campur Kode Berwujud Kalimat}

Campur kode berwujud kalimat tampak dalam kutipan wawancara berikut.

\begin{tabular}{|c|c|}
\hline Pewawancara & $\begin{array}{l}\text { Would you like to tell me about } \\
\text { about one mistake that you have } \\
\text { learnt from it. Kamu pernah } \\
\text { berbuat salah? }\end{array}$ \\
\hline Peserta wawancara & $\begin{array}{l}\text { Yes, saya pernah melakukan } \\
\text { kesalahan. Dengan ibu tak pernah } \\
\text { akur. Tetapi setelah saya cukup } \\
\text { besar saya sadar dan saya } \\
\text { meminta maaf kepada ibu saya. } \\
\text { Sejak saat itu saya sangat } \\
\text { menghormati ibu saya. }\end{array}$ \\
\hline
\end{tabular}

(CK/D-11/PIB/2018)

Pada data 11, ditemukan adanya campur kode bahasa Inggris dan Indonesia yang dilakukan oleh peserta wawancara. Pertanyaan pewawancara dijawab oleh peserta wawancara dengan menggunakan dua bahasa yaitu bahasa Inggris yes dan bahasa Indonesia saya pernah melakukan kesalahan. Dengan ibu tak pernah akur. Tetapi setelah saya cukup besar saya sadar dan saya memnta maaf kepada ibu saya. Sejak saat itu saya sangat menghormati ibu saya. Kutipan wawancara tersebut digolongkan dalam bentuk campur kode berwujud kalimat.

Campur kode berwujud kalimat juga dapat ditemukan dalam kutipan wawancara berikut.

Pewawancara

Give me an example how you will follow the rules in PIB bisakah kamu kasih contoh bagaimana kamu mematuhi peraturan?

Peserta wawancara : Saya akan disiplin

(CK/D-12/PIB/2018)

Dalam kutipan wawancara tersebut, pewawancara bertanya kepada peserta wawancara dengan menggunakan dua Bahasa yaitu Bahasa Inggris dan Bahasa Indonesia. Bisakah kamu kasih contoh bagaimana kamu mematuhi peraturan? Adalah kalimat tanya yang dilontarkan oleh pewawancara setelah ia melontarkan kalimat tanya menggunakan Bahasa Inggris give me an example how you will follow the rules in PIB. Campur kode pada data 12 tersebut digolongkan dalam campur kode ekstern.

Pada data wawancara berikut ditemukan pula campur kode berwujud kalimat.

\begin{tabular}{|c|c|c|}
\hline Pewawancara & : & $\begin{array}{l}\text { What is your greater strengts? } \\
\text { Apa kekuatan terbesar yang } \\
\text { kamu miliki? }\end{array}$ \\
\hline $\begin{array}{l}\text { Peserta } \\
\text { wawancara }\end{array}$ & : & $\begin{array}{l}\text { Oh kekuatan apa? I have big and } \\
\text { diligent }\end{array}$ \\
\hline Pewawancara & : & $\begin{array}{l}\text { How about motivation discipline, } \\
\text { and communication? }\end{array}$ \\
\hline Pewawancara & : & $\begin{array}{l}\text { Yes, I think discipline and } \\
\text { communication }\end{array}$ \\
\hline
\end{tabular}

(CK/D-13/PIB/2018)

Kutipan pertanyaan What is your greater strengts? Apa kekuatan terbesar yang kamu miliki? Yang dilontarkan oleh pewawancara adalah dua kalimat yang artinya sama, namun digunakan dalam dua bahasa, yaitu kalimat What is your greater strengts dalam bahasa Inggris dan kalimat Apa kekuatan terbesar yang kamu miliki? dalam bahasa Indonesia. Kalimat yang digunakan oleh pewawancara tersebut termasuk dalam campur kode berwujud kalimat.

Kutipan wawancara berikut juga tergolong dalam campur kode berwujud kalimat.

\begin{tabular}{|c|c|c|}
\hline Pewawancara & : & $\begin{array}{l}\text { Kamu sekarang kan diterima } \\
\text { sebagai calon, correct? }\end{array}$ \\
\hline Peserta wawancara & : & Yes correct \\
\hline Pewawancara & : & $\begin{array}{l}\text { Sebagai calon dapat diterima } \\
\text { dapat juga tidak, right? }\end{array}$ \\
\hline Peserta wawancara & $:$ & Yes \\
\hline Pewawancara & : & $\begin{array}{l}\text { Apa kira-kira timbal balik yang } \\
\text { kamu berikan kepada PIB kalau } \\
\text { kamu diterima, free tuition fee? }\end{array}$ \\
\hline $\begin{array}{l}\text { Peserta wawancara } \\
\text { CK/D-18/PIB/2018) }\end{array}$ & : & Belajar dengan tekun \\
\hline
\end{tabular}

Dalam kutipan wawancara tersebut, ditemukan adanya dua bahasa yang digunakan oleh pewawancara dan peserta wawancara. Hal ini dibuktikan dengan munculnya kalimat berbahasa Indonesia Kamu sekarang kan diterima sebagai calon, dan diikuti dengan bahasa Inggris correct? Selain itu, ditemukan pula campur kode berwujud kalimat Sebagai calon dapat diterima dapat juga tidak, right? Dan Apa kira-kira timbal balik yang kamu berikan kepada PIB kalau kamu diterima, free tuition fee? Campur kode berwujud kalimat tersebut digolongkan dalam campur kode ekstern.

\section{Bentuk Alih Kode Antara Peserta wawancara "PIB Berbagi" Gelombang dengan Tim Pewawancara}

Alih kode dapat diartikan sebagai peristiwa peralihan dari kode yang satu ke kode yang lain. Alih kode dapat berupa alih kode gaya, ragam, maupun variasi-variasi bahasa yang lainnya. Menurut Suwito (1985:68) alih kode terjadi apabila seseorang penutur semula menggunakan kode A (misalnya 
bahasa Indonesia), kemudian beralih menggunakan kode B (misalnya bahasa daerah/asing). Alih kode pada umumnya terjadi karena alasan tertentu dan motivasi tertentu.

\section{Alih Kode Berwujud Klausa}

Penggunaan alih kode berwujud klausa antara peserta wawancara dan tim pewawancara seleksi masuk "PIB Berbagi" dapat ditemukan dalam data-data berikut ini.

$\begin{array}{lll}\text { Pewawancara } & : & \begin{array}{l}\text { So, about your father and your } \\ \text { mother, what are they doing? }\end{array} \\ \text { Peserta wawancara } & : & \begin{array}{l}\text { More less one man both of the } \\ \text { them be get money }\end{array} \\ \text { Pewawancara } & & \text { how much? } \\ \text { Peserta wawancara } & : & \text { Maybe one million, satu juta } \\ \text { Pewawancara } & : & \text { One person one million? } \\ \text { Peserta wawancara } & : & \text { Iya itu kurang lebih } \\ \text { (AK/D-5/PIB/2018) } & & \end{array}$

Pada data 5, pertanyaan yang dilontarkan oleh pewawancara one person one million? dijawab oleh peserta wawancara dengan menggunakan bahasa Indonesia Iya itu kurang lebih. Berdasarkan data tersebut ditemukan adanya alih kode berwujud klausa bahasa Inggris one person one million? ke klausa bahasa Indonesia Iya itu kurang lebih. Peristiwa komunikasi ini digolongkan dalam alih kode ekstern.

Bentuk alih kode berwujud klausa juga ditemukan dalam data berikut.

$\begin{array}{lll}\text { Pewawancara } & : & \text { Have you worked before in hotel? } \\ \text { Peserta wawancara } & : & \text { Yes } \\ \text { Pewawancara } & : & \text { When? } \\ \text { Peserta wawancara } & : & \text { Tahun lalu } \\ \text { (AK/D-16/PIB/2018) } & & \end{array}$

Dalam kutipan wawancara di atas, pewawancara bertanya Have you worked before in hotel dan peserta wawancara menjawab yes. Jawaban peserta wawancara mengundang tanya lebih lanjut dari pewawancara yaitu when lalu peserta wawancara menjawabnya tahun lalu. Jawaban yang dilontarkan oleh peserta wawancara dalam bentuk bahasa Indonesia. Dalam peristiwa komunikasi tersebut ditemukan terjadinya alih kode bahasa Inggris ke bahasa Indonesia. Alih kode dalam kutipan wawancara ini tergolong dalam alih kode bahasa ekstern.

\section{Alih Kode Berwujud Kalimat}

Bentuk alih kode berwujud kalimat dapat ditemukan dalam data berikut ini:

$\begin{array}{ll}\text { Pewawancara } \quad: \quad \begin{array}{l}\text { If you are admitted to PIB, will you } \\ \text { agree to follow all rules in PIB, jika } \\ \text { diterima di PIB apakah Anda mau } \\ \text { mengikuti semua aturan yang } \\ \text { ditetapkan atau Anda pilih-pilih do you } \\ \text { have experience in kitchen or library? }\end{array} \\ \begin{array}{l}\text { Peserta } \\ \text { wawancara }\end{array} & \text { Yes, I have }\end{array}$

Pewawancara

Peserta

wawancara

(AK/D-8/PIB/2018)

Pada data 8, pewawancara melakukan alih kode dari bahasa Inggris If you are admitted to PIB, will you agree to follow all rules in PIB ke dalam bahasa Indonesia jika diterima di PIB apakah Anda mau mengikuti semua aturan yang ditetapkan atau Anda pilih-pilih lalu dialihkan lagi ke dalam bahasa Inggris do you have experience in kitchen or library? peralihan kode tersebut digolongkan ke dalam alih kode ekstern.

Alih kode berwujud kalimat juga ditemukan pada data berikut.

Pewawancara

Peserta
wawancara
Pewawancara

Peserta

wawancara

(AK/D-6/PIB/2018)

Pewawancara dalam data 6 melakukan alih kode bahasa Inggris ke bahasa Indonesia. Kalimat berbahasa Inggris Who has inspired you in your life? Diikuti dengan kalimat berbahasa Indonesia Siapa yang menginspirasi dalam hidup Anda? wujud alih kode pada data 6 tersebut digolongkan dalam alih kode ekstern.

Fungsi Campur Kode dan Alih Kode Antara

Peserta Wawancara "PIB Berbagi" Tahun

Akademik 2018-2019 dengan Tim Pewawancara

Fungsi bahasa secara umum ialah untuk berkomunikasi. Pemakai bahasa menggunakan bahasa dengan maksud dan tujuan tertentu. Berdasarkan temuan yang didapat, fungsi penggunaan kode bahasa dalam kegiatan tes wawancara yang dilakukan di Politeknik Internasional Bali (PIB) ialah sebagai berikut.

\section{Fungsi untuk Menegaskan Maksud}

Pewawancara dan peserta wawancara "PIB Berbagi" melakukan alih kode dan campur kode dengan tujuan untuk menegaskan maksud seperti yang ditemukan dalam data berikut.

Pewawancara : Let us start from your experience during the first, second, and third grade of Senior High School, can you tell me, what is your favourite subject? Pelajaran apa yang disukai? 


\section{Peserta : Matematika}

wawancara

(CK/D-4/PIB/2018)

Pada data 4, pewawancara mengulangi pertanyaan tentang pelajaran apa yang disukai oleh peserta wawancara semasa sekolah dengan menggunakan bahasa Indonesia dengan tujuan untuk menegaskan maksud pertanyaan pewawancara.

Demikian juga yang ditemukan pada data berikut.

Pewawancara

Pewawancara

Peserta wawancara (CK/D-8/PIB/2018)

Pada data 8, pewawancara bertanya dengan menggunakan dua bahasa yaitu bahasa Inggris dan bahasa Indonesia. Pertanyaan dalam bahasa Inggris tentang kesediaan peserta wawancara untuk mematuhi peraturan di PIB jika ia diterima diulanginya kembali dengan menggunakan bahasa Indonesia. Dalam konteks ini, tampak jelas maksud pewawancara mengulangi kembali pertanyaannya ialah untuk menegaskan tentang peraturan yang akan patuhi jika diterima di PIB.

Selain itu, fungsi untuk menegaskan maksud juga ditemukan dalam data berikut.

\begin{tabular}{|c|c|c|}
\hline Pewawancara & : & $\begin{array}{l}\text { Who has inspired you in your } \\
\text { life? Siapa yang menginspiras } \\
\text { dalam hidup Anda? }\end{array}$ \\
\hline Peserta wawancara & : & Mom \\
\hline Pewawancara & : & $\begin{array}{l}\text { Why? Tell me about your mom } \\
\text { why she is a role mode? }\end{array}$ \\
\hline Peserta wawancara & : & $\begin{array}{l}\text { She is my motivation, sebagai } \\
\text { penyemangat }\end{array}$ \\
\hline
\end{tabular}

(CK/D-6/PIB/2018)

Pada data 6, kalimat siapa yang menginspirasi dalam hidup Anda? adalah wujud bahasa Indonesia setelah pewawancara bertanya dalam bahasa Inggris who has inspired you in your life? Dalam konteks ini pewawancara melakukan alih kode dari bahasa Inggris ke bahasa Indonesia dengan maksud untuk menegaskan maksudnya tentang orang yang menginspirasi hidupnya.

Pewawancara : Would you like to tell me about about one mistake that you have learn from it. Kamu pernah berbuat salah?

\section{Peserta \\ wawancara}

(CK/D-11/PIB/2018)

Pada data 11, pewawancara meminta peserta wawancara untuk menceritakan sebuah kesalahan yang pernah dilakukan oleh peserta wawancara. Untuk menegasi pertanyaan sekaligus permintaannnya, pewawancara melakukan alih kode dari bahasa Inggris ke bahasa Indonesia dengan satu jenis pertanyaan. Dalam konteks tersebut, pewawancara melakukan alih kode dengan maksud untuk menegaskan maksud.

Demikian juga fungsi alih kode dan campur kode yang ditemukan dalam data berikut.

$\begin{array}{lll}\text { Pewawancara } & : \text { What is your greater strengts? } \\ & \begin{array}{l}\text { Apa kekuatan terbesar yang kamu } \\ \text { miliki? }\end{array} \\ \text { Peserta } & : \begin{array}{l}\text { Oh kekuatan apa? I have big and } \\ \text { wawancara }\end{array} & \begin{array}{l}\text { diligent } \\ \text { Pewawancara }\end{array} \\ \text { Pewawancara } & : \begin{array}{l}\text { And communication? } \\ \text { Yes, I think discipline and } \\ \text { comunication }\end{array}\end{array}$

(CK/D-13/PIB/2018)

Pada data 13, kalimat pertanyaan yang dilontarkan oleh pewawancara What is your greater strengts? Diikuti dengan kalimat pertanyaan yang sama tetapi dalam bahasa Indonesia Apa kekuatan terbesar yang kamu miliki? Fungsi alih kode yang ditemukan dalam data 13 ini ialah untuk menegaskan maksud pewawancara yaitu tentang kekuatan terbesar yang pernah dimiliki oleh peserta wawancara.

Fungsi alih kode dan campur kode untuk menegaskan maksud ditemukan dalam data berikut.

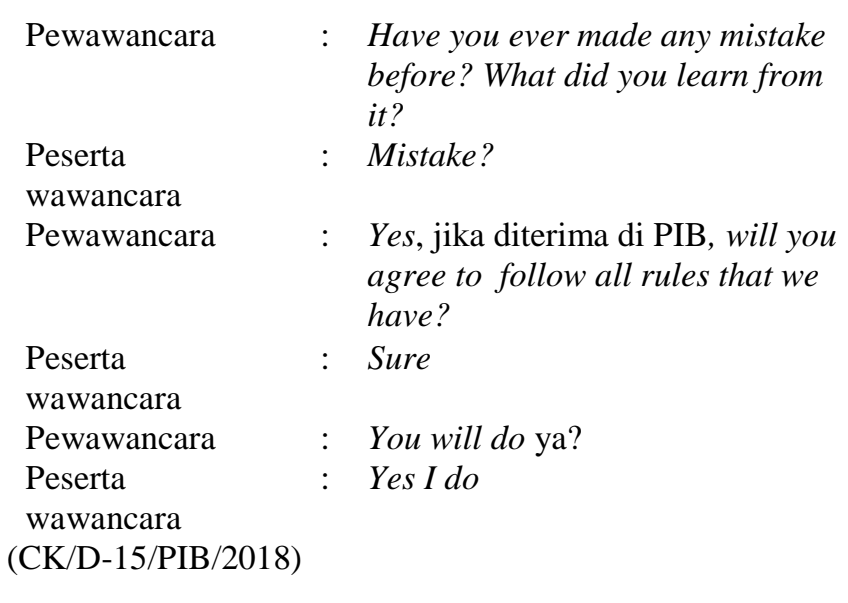

Pada data 15, campur kode yang dilakukan oleh pewawancara you will do ya? Bertujuan untuk menegaskan maksud pewawancara sekaligus memastikan bahwa peserta wawancara wajib mengikuti setiap peraturan yang berlaku di PIB jika diterima sebagai mahasiswa PIB. 


\section{Fungsi untuk Memberikan Informasi}

Fungsi alih kode dan campur kode untuk memberikan informasi dapat dijumpai dalam data berikut.

$\begin{array}{ll}\text { Pewawancara } & : \quad \begin{array}{l}\text { So, about your father and your } \\ \text { mother, what are they doing? }\end{array} \\ \begin{array}{l}\text { Peserta } \\ \text { wawancara }\end{array} & \begin{array}{l}\text { More less one man both of the } \\ \text { them be get money }\end{array} \\ \begin{array}{l}\text { Pewawancara } \\ \text { Peserta }\end{array} & \text { how much? } \\ \text { wawancara } & : \text { Maybe one million, satu juta } \\ \text { Pewawancara } & : \text { One person one million? } \\ \begin{array}{l}\text { Peserta } \\ \text { wawancara } \\ \text { (CK/D-5/PIB/2018) }\end{array} & : \text { Iya itu kurang lebih }\end{array}$

Frasa maybe one million yang diutarakan oleh peserta wawancara pada data 5 tersebut diikuti dengan frasa satu juta. Tuturan tersebut berfungsi untuk memberikan informasi.

Fungsi campur kode untuk memberikan juga ditemukan pada data berikut.

$\begin{array}{ll}\text { Pewawancara } & : \begin{array}{l}\text { Do you have achievement or a } \\ \text { accomplishment you are? }\end{array} \\ \text { Peserta } & : \quad \begin{array}{l}\text { I have juara satu lomba baca tulis } \\ \text { cerpen and itu juga ke Manado } \\ \text { wawancara }\end{array} \\ \text { (CK/D-2/PIB/2018) } & \end{array}$

Pada data 2, peserta wawancara menceritakan tentang prestasi yang pernah diraihnya diawali dengan penggunaaan bahasa Inggris I have dan diteruskan dengan bahasa Indonesia juara satu lomba baca tulis cerpen and itu juga ke Manado. Fungsi dari alih kode yang ditemukan dalam data 2 tersebut ialah untuk memberikan informasi.

Fungsi alih kode untuk memberikan informasi juga ditemukan dalam data berikut.

$\begin{array}{ll}\text { Pewawancara } & : \text { Who is the your } \\ & \text { inspiration? } \\ \text { Peserta wawancara } & : \text { My parents } \\ \text { Pewawancara } & : \text { Why? } \\ \text { Peserta wawancara } & : \text { Because my parents is } \\ & \text { mencontohkan hal yang } \\ & \text { baik dalam hidupku }\end{array}$

(AK/D-17/PIB/2018)

Pada data 17, alih kode dari bahasa Inggris ke Bahasa Indonesia yang dilakukan oleh peserta wawancara ketika menjelaskan tentang orang yang menginspirasi hidupnya selain berfungsi untuk memberikan informasi. Ketika pewawancara menanyai mengapa orang tua dikatakan sebagai penginspirasi hidupnya, peserta wawancara menjawab dengan menggunakan dua Bahasa yaitu Bahasa Inggris dan Bahasa Indonesia. Peristiwa alih kode dari Bahasa Inggris ke Bahasa Indonesia pada data tersebut berfungsi untuk menjelaskan dan menginformasikan bahwa orang tua peserta wawancara senantiasa mencontohi hal-hal positif untuk anaknya.

Fungsi alih kode untuk memberikan informasi juga ditemukan dalam data berikut.

$\begin{array}{lll}\text { Pewawancara } & : \text { Have you worked before in hotel? } \\ \begin{array}{l}\text { Peserta } \\ \text { wawancara }\end{array} & : \text { Yes } \\ \begin{array}{l}\text { Pewawancara } \\ \text { Peserta }\end{array} & : \text { When? } \\ \text { wawancara } & & \end{array}$

(AK/D-16/PIB/2018)

Tampak ketika pewawancara menanyakan dengan menggunakan bahasa Inggris Have you worked before in hotel? When? peserta wawancara menjawabnya dengan menggunaan bahasa Indonesia Tahun lalu. Peristiwa alih kode yang dilakukan oleh peserta wawancara ketika menjawab pertanyaan pewawancara dengan menggunakan bahasa Indonesia berfungsi untuk memberikan informasi.

\section{Fungsi untuk Mengakrabkan diri}

Peristiwa alih kode dan campur kode yang dilakukan antara pewawancara dan peserta wawancara tidak hanya berfungsi untuk menegaskan maksud dan menginformasikan sesuatu, namun juga berfungsi untuk mengakrabkan diri.

Berikut kutipannya:
Pewawancara : So, do you have any experience when you feel that you have done something wrong?

\section{Peserta : Punya}

wawancara

Pewawancara Kesalahan apa?

Peserta

wawancara Waktu SD, my friend always juara 1 and then saya merasa iri. Dari situlah saya mulai belajar, study again, again, dan again and finally SMP saya mendapat juara 1 sampai SMA

Pewawancara Actually, your friends is the one who gives you motivation

(CK/D-7/PIB/2018)

Pada data 7, peserta pewawancara berusaha untuk mengakrabkan diri dengan melakukan campur kode bahasa Inggris dan bahasa Indonesia Waktu SD, my friend always juara 1 and then saya merasa iri. Dari situlah saya mulai belajar, study again, again, dan again and finally SMP saya mendapat juara 1 sampai SMA. Peserta wawancara dalam konteks ini berusaha mengakrabkan diri dan membuat suasana terlihat tampak santai dengan melakukan campur kode antara bahasa Inggris dan bahasa Indonesia. Dalam data tersebut, tampak jelas fungsi campur kode yang dilakukan pewawancara dan peserta wawancara ialah untuk mengakrabkan diri. 


\section{SIMPULAN}

Berdasarkan uraian di atas dapat disimpulkan:

1. Campur kode dan alih kode yang digunakan oleh pewawancara dan peserta wawancara "PIB Berbagi" Tahun Akademik 2018-2019 berwujud kata, frasa, klausa, dan kalimat. Wujud campur kode dan alih kode tersebut digolongkan dalam jenis campur kode dan alih kode ekstern, yaitu variasi kode bahasa Indonesia dan bahasa asing, dalam hal ini bahasa Inggris.

2. Adapun fungsi campur kode dan alih kode yang ditemukan dalam penelitian ini ialah 1) berfungsi untuk menegaskan sesuatu, 2) berfungsi untuk menginformasikan sesuatu, dan 3) berfungsi untuk mengakrabkan diri.

\section{Saran}

Hasil penelitian ini diharapkan dapat memberikan kontribusi positif baik dalam bidang kebahasaaan maupun dalam bidang kepariwisataan. Adapun saran dalam penelitian ini ialah sebagai berikut.

1. Penelitian ini diharapkan dapat berkontribusi bagi civitas academica PIB. Melalui penelitian ini, civitas academica PIB diharapkan memiliki pemahaman yang luas tentang alih kode dan campur kode serta mengaplikasikannya dalam kegiatan berbahasa sehari-hari sebagai sebuah komunikasi yang positif.

2. Penelitian ini bisa dijadikan titik tolak untuk melakukan penelitian-penelitian lainnya diantaranya ialah meneliti sikap berbahasa mahasiswa, respon mahasiswa terhadap pemakaian bahasa Indonesia dalam dunia pariwisata, dan sebagainya secara intensif dengan jangkauan yang lebih luas dan dalam.

\section{DAFTAR PUSTAKA}

Ariyani, Munaris, dan Murniati. (2015). “Alih Kode dan Campur Kode pada mahasiswa PBSI dan Implikasinya". Jurnal Kata (Bahasa, Sastra, dan Pembelajarannya). Vol 2(1) hal. 26-37.

Fathurrohman, Sumarti, dan Sri Hastuti. (2013). "Bentuk dan Fungsi Campur Kode dan Alih Kode pada Rubrik "Ah...Tenane" Dalam Harian Solopos". BASASTRA Jurnal Penelitian Bahasa, Sastra Indonesia, dan Pengajarannya. Vol 2(1) hal.11-23.

Mahsun. (2012). Metode Penelitian Bahasa Tahapan strategi, metode, dan tekniknya. Jakarta: Rajawali Pers.

Moleong, Lexy.J. (2007). Metodologi Penelitian Kualitatif. Bandung: Rosdakarya.

Mustikawati, Diyah Atiek. (2015). “Alih kode dan Campur Kode antara Penjual dan Pembeli (Analisis Pembelajaran Bahasa Melalui Studi Sosiolinguistik". Jurnal Dimensi Pendidikan dan Pembelajaran. Vol 3(2) hal.23-32.

Nababan, P.W.J. (1993). Sosiolinguistik. Bandung: Angkasa.

Poedjosoedarmo, S. (1976). Pengaruh Bahasa Indonesia terhadap Bahasa Jawa. Yogyakarta: Stensilan.
Sugiyono. (2009). Metode Penelitian Kuantitatif Kualitatif dan $R \& D$. Bandung: ALFABETA.

Suwito.(1985). Solinguistik Pengantar Awal. Edisi ketiga. Surakarta: Universitas Sebelas Maret. 